Imaging America: Stephen Crane's The Red Badge of Courage and Visual Representations of the Civil War

\author{
Eric Johann Gislason \\ Fairbanks, Alaska
}

B.A., University of Puget Sound, 1992

M. A. T., University of Puget Sound, 1993

A Thesis presented to the Graduate Faculty of the University of Virginia in Candidacy for the Degree of Master of Arts

Department of English

University of Virginia

August 1996

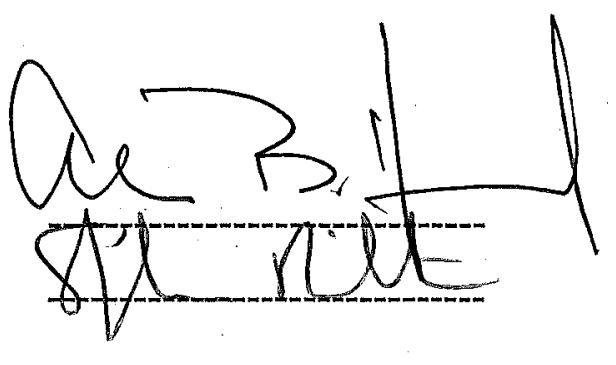


$A L D$

Masters

English

1996

. 657

$=$ 


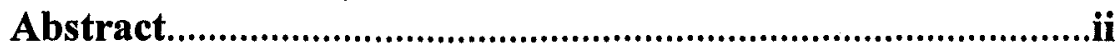

Critical Reception: Early Reviews...........................................1

The Battle: Chancellorsville..................................................10

Imaging the Civil War: Authenticity in Painting, Photography and The Red Badge of Courage............................22

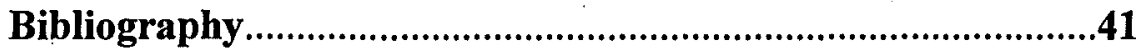

This M. A. thesis is intended to be viewed in its original incarnation as a hypertextual preface to an on-line edition of Stephen Crane's The Red Badge of Courage. It resides at:

http://xroads.virginia.edu/ HYPER/CRANE/title.html 


\title{
IMAGING AMERICA: STEPHEN CRANE'S THE RED BADGE OF COURAGE AND VISUAL REPRESENTATIONS OF THE CIVIL WAR
}

\begin{abstract}
Some early reviews of Stephen Crane's The Red Badge of Courage (1895) expressed bemusement and discontent with his abandonment of many of the narrative and stylistic conventions of contemporary realism (the tradition of historical romance as it descended from Scott). But others praised the novel's originality, its "photographic revelation" and rendering of the theatre of war. Such disagreement suggests that Crane's novel participates in what Miles Orvell has called the central category of post-photographic American culture: the dialectic of imitation and authenticity. The cultural and artistic quest for authenticity--the apprehension of a "real" that is more than a collection of facts or a mere imitation of surface reality--preoccupied visual and narrative artists in the latter half of the 19th century. In pursuit of authenticity, Crane ignored his literary precursors and drew inspiration for his novel from images of the Civil War which persisted in the public imagination: photographs by Brady, Gardner, and O' Sullivan; paintings by Homer and others. Red Badge's discontinuous succession of "battle pictures" questions the narrative strategies of contemporaneous fictional and historical accounts of the War, critiques their unsatisfactory, often self-congratulatory answers about its significance to American society. The novel is not strictly concerned with imaging the violence, confusion, and death of war: in Crane's portrait of Henry struggling with his comrade to uphold the colors on the battlefield can
\end{abstract}


be seen the seed of what Ralph Ellison has called the "antagonistic cooperation" so crucial to democratic society. Both Henry and the loud soldier have learned that the justification of one's life must come from its dedication to a community, and that the virtues so instinctual in war are also important to everyday life.

The first section of the project, "Critical Reception: Early Reviews," examines the responses of several of Crane's contemporaries. George Wyndham and Harold Frederic celebrate Crane's fresh presentation and original vision, drawing comparisons between his prose and photography. The contributions to the Dial controversy remind readers that perhaps Red Badge is in fact a more political novel than many subsequent critics have deemed it to be.

The second section, "The Battle: Chancellorsville," argues that Crane set Red Badge in a specific historical situation: the bloody Civil War battle of Chancellorsville. This particular battle suits Crane's historical and thematic purposes: it was the first battle for many regiments (as it is for Henry's); it was bloody--a total of 27,000 men lost their lives; it brought embarrassment and near disaster to the Union while serving only as a pyrrhic victory for the South's losing cause. Crane's reliance on Century magazine's Battles and Leaders of the Civil War for the factual framework of his narrative is carefully outlined here, as is his use of many of that volume's illustrations as inspiration for scenes in Red Badge.

With the identification of Crane's artistic and cultural concerns--a rejection of the generic conventions of popular fictions about the war and a revisionist interpretation of the Civil War's significance to American history--comes an examination of Crane's 
reliance on well-known visual representations of the War to address these concerns. The concluding section of the project, "Imaging the Civil War: Authenticity in Painting, Photography, and The Red Badge of Courage," suggests that Crane drew on visual representations of the Civil War by Brady, Gardner, Homer, O' Sullivan and others to critique contemporary attitudes toward the Civil War. Brady and O' Sullivan's photographs of the Civil War dead are of corpses produced by the machine of war, not heroic knights of old. Crane, like Brady and perhaps others, stages his battle pictures to imortant rhetorical effect: he questions the myth of valorous death, asking: Why are these men here? Henry is himself, despite all his experience, unable to definitively answer this question. Crane emphasizes, as well, the loneliness and isolation of the soldier's experience so powerfully rendered in Homer's paintings of Civil War experience. Evoking the Homer's "The Veteran in a New Field," Crane portrays Henry's initiation into war with irony--it is difficult to think of Henry as a hero in any conventional sense--but also with a wistfulness that suggests Henry has at last found reasons to be devoted to a cause larger than himself. 


\section{Critical Reception: Early Reviews}

\section{INTRODUCTION}

Commonly considered Stephen Crane's greatest accomplishment, The Red Badge of Courage (1895) ranks among the foremost literary achievements of the modern era. When its publication was announced in Publisher's Weekly on 5 October 1895, Crane was largely unknown. Although his volume of poetry published earlier that year, The Black Riders, had made some waves in literary circles, it struck most readers as quirky and cryptic. The gritty social realism of his first novel, Maggie: A Girl of the Streets (1893) had earned praise from literati such as Hamlin Garland and W. D. Howells, but Crane probably gave away more copies than were actually sold. (The story is told that Crane, in a desperate advertising scheme, paid men to ride the Manhattan El train and conspicuously read copies of Maggie.) When Crane signed a contract with D. Appleton and Co. to publish Red Badge, he was not well-known enough to command an advance, and agreed to a flat 10 per cent royalty on the retail price of all copies sold (Weatherford, 5). Published in the autumn of 1895 , Red Badge went through two editions before the end of the year. By March of 1896 the novel was in eighth place on the international booksellers' list and had gone through fourteen printings; remarkably enough, Red Badge has never been out of print (6). Unfortunately, unremunerative contracts with publishers and a general lack of good business sense kept Crane insolvent for much of his life. But with the publication of Red Badge, Crane achieved almost overnight celebrity. 
During Crane's lifetime, public interest often focused on his personal life--his bohemian lifestyle, daring journalistic exploits, and eventual expatriation to Britain-rather than on his writings. Much of the initial press about Crane's novel was full of speculation about who he was, where he came from, and how he could write so convincingly about a war he had never seen. Nevertheless, early reviewers of Red Badge introduced many of the issues which have remained of interest in subsequent critical investigations of Crane's work. His "war novel" won him widespread international praise, from admiring newspaper notices like those in the New York Times and the Philadelphia Press to the more discerning responses of critics such as Englishman George Wyndham and the contemporary dean of American letters, William Dean Howells. For a list of several of the important early reviews of Red Badge, consult the Reviews page of this project (Appendix A).

\section{BRITISH REVIEWS}

British and American reviewers argued quite a bit about who should get credit for the "discovery" of Crane. While the novel was not universally praised, almost without exception Crane's critics marveled at the emotional power of his vivid, visual prose. Some critics groused about Crane's idiosyncratic grammar--he begins one sentence with "Too," for example--while some others who became involved in the Dial controversy voiced discontent about what they perceived to be Crane's lack of patriotism. English critics tended to take Red Badge more seriously than their American counterparts, 
pointing out its affinities with works by Tolstoy, Zola, Kipling, and the battle scenes of the Russian realist painter Verestschagin (13). The English critic Sydney Brooks, totally convinced by Crane's depictions of combat in Red Badge, assumed that Crane had fought in the Civil War. If Red Badge were "altogether a work of the imagination, unbased on personal experience," Brooks asserted, "its realism would be nothing short of a miracle." Crane's imaginative effort remains a marvel.

Perhaps the most perceptive of Crane's English critics was George Wyndham, a Member of Parliament and veteran of the British army. Wyndham was the only one of Crane's early critics to grasp the significance of narrating the novel from the point of view of Private Henry Fleming. Generals' accounts, Wyndham noted, had usually been written from the "band-box" viewpoint and emphasized large-scale concerns (troop movements, tactical maneuvers, wins and losses), neglecting the much more limited but in many ways more intense experience of the anonymous foot soldier. ("The real war," Walt Whitman had declared in his Civil War memoir Specimen Days [1882], "will never get in the books.") What distinguished Crane in his effort to portray modern warfare was his use of what Wyndham called a "new device," that of focusing on the youth and tracing the successive impressions made by the picturesque and emotional experience of war on his "morbidly sensitive" temperament. Wyndham wrote: "[Crane] stages the drama of war, so to speak, within the mind of one man, and then admits you as to a theatre." Crane's reportage of the "procession of flashing images shot through the senses into one brain" combined the "strength and truth of a monodrama with the directness and color of the best narrative prose" (109-110). Wyndham found Crane's account authentic, Henry's soul 
"truly drawn."

Much of the impact of Red Badge arose, then, from its powerful pictures of war, the images that leapt off the page into the mind of the reader. But equally important in Wyndham's review was his illumination of the intersection between the picturesque and ethical aspects of the novel. Given that Henry had enlisted in "hasty pursuit of a vanishing ambition," Wyndham suggested that Crane's "battle pictures" were used to dramatize the replacement of Henry's early "tinsel bravado" with his later discovery of "courage in the bedrock of primeval antagonism" (113). Henry's tragic resignation to duty--his commitment to a cause larger than himself--is his final acknowledgment that the "justification of any one life lies in its perfect adjustment to others." Crane's account prophesies the regeneration of America at the same time it suggests the insignificance of heroes. Readers of Red Badge, Wyndham concluded, should infer from Henry's experience that "the virtues so instinctual in moments of distress may be useful also in everyday life" (114).

\section{AMERICAN REVIEWS}

Early American reviewers of Red Badge were generally not as incisive as Wyndham. Perhaps most surprisingly, one American critic writes suggests that in the novel "a serio-comic effect seems to be intended throughout" (Weatherford, 15). William Dean Howells, writing in Harper's Weekly, praises Crane's "divinations of motive and experience" but expresses doubt about whether Crane can be considered a "realist" writer, 
preferring to call his prose style "impressionistic" (critics still debate about which, if either, of these labels to use). Novelist Harold Frederic, London editor of the New York Times, recognized Red Badge as a masterpiece. He wrote that it would likely be "one of the deathless books which must be read by everybody who desires to be, or to seem, a connoisseur of modern fiction" (116). From our current perspective we can see that Frederic was right: Crane's journalistic description and ironic understatement comprise a stylistic legacy which has descended through Hemingway and early Mailer and done a great deal in shaping American literature as we know it (Delbanco, 57).

Like many early reviewers, Frederic expressed admiration for the emotional power of Crane's work, but he was one of the very few who recognized the boldness and originality of Crane's technique. "The Red Badge," Frederic claimed, "impels the feeling that the actual truth about a battle has never been guessed before" (Weatherford, 116). Like Wyndham before him, who had compared the novel to a monodrama presented in the "theatre" of war, Frederic emphasized the novel's visual aspects and its radical reduction in point of view and narrative scope. "We do not know, or seek to know...anything...except what, staring through the eyes of Henry Fleming, we are permitted to see" (117). Red Badge was a "tremendously effective battle painting;" the trial of a soldier in war, he maintained, "seems never to have been painted as well before" (118). Henry's actions seemed the actions of the readers' own minds.

But later in his review Frederic made a more suggestive assessment. Acknowledging that battle painters have always depicted horses in motion "not as they actually move, but as it has been agreed by numberless generations of draughtsmen to say 
that they move," Frederic held that Crane's novel shatters such conventions. "At last, along comes a Muybridge [American photographer who specialised in pictures of animals in motion], with his instantaneous camera, and shows that the real motion is entirely different." Red Badge is remarkable for its abandonment of painterly conventions and conveyance of a "photographic revelation." Frederic concludes that the authenticity of Crane's vision is a "novel force" which may do other "remarkable things" (119). This intelligently enthusiastic review of the novel did much to focus international attention on the relatively unknown Crane. The two men became friends but remained literary rivals: Frederic's The Damnation of Theron Ware outsold Red Badge in 1896.

\section{THE DLAL CONTROVERSY}

One of the most notable features of Red Badge's reception in America is the controversy about Crane's patriotism that raged in the pages of the Dial, a magazine owned by the conservative General Alexander C. McClurg. The outspoken McClurg, who had risen to the rank of Brigadier-General in the Northern Army, attacked Crane for portraying a Union soldier as a coward. Although Dial editor William Morton Payne had already made evident the magazine's disapproval of Red Badge, McClurg maintained that Payne's assessment had not been unfavorable enough. Criticizing those English and American reviewers who had praised Red Badge, McClurg fumed at what he saw as another installment in the habitual English ridicule of American soldiers: Mistakenly assuming that Crane's novel had been first published in England, McClurg denounced it 
as a "vicious satire upon American soldiers and American armies," as part of a plot to undermine confidence in the nation's armed forces (15). Such books, McClurg finished, should never be allowed to be published in America.

The first response to General McClurg's broadside came in a letter from J. L. Onderdonk, who, expressing his agreement with McClurg's position, ridiculed Red Badge as a "literary absurdity." In the same issue of the Dial, Ripley Hitchcock writes to the editors on behalf of the publishers of the novel, D. Appleton \& Co. In an understated tone which contrasts pointedly with McClurg's heated prose, Hitchcock points out and corrects some of the General's mistakes while reminding readers of the numerous favorable notices garnered by the novel. English critic Sydney Brooks, who had earlier praised Red Badge in the Saturday Review, wrote to the Dial in defense of Crane's novel. Dismissing McClurg's incendiary speculations about English opinion of the novel as "misjudged patriotism and bad criticism," Brooks rightly points out that McClurg's notion of literary standards constituted a form of censorship which would allow only the most celebratory accounts of American life to be published (16). The good-natured good sense of Brooks' letter ended the Dial controversy.

\section{CONRAD AND THE CURRENT SCENE}

A quarter-century after Crane's death, Joseph Conrad remembered in Last Essays (1926) that the appearance of Red Badge had been "one of the most enduring memories of my literary life." Calling Crane "non-comparable" as an artist, Conrad notes 
sorrowfully that Crane's life bore a marked parallel with that of Red Badge's "tattered soldier": "it was his fate, too, to fall early in the fray." Today, Crane's critical reputation remains strong, and a resurgence of attention to literary realism--New Essays on the Red Badge of Courage (1986), Amy Kaplan's The Social Construction of American Realism (1988), Giorgio Mariani's Spectacular Narratives: Representations of Class and War in the American 1890s (1992)--demonstrates the continued centrality of many of the questions expressed by the early reviewers of Red Badge. Much of this recent criticism grapples with issues first raised in Wyndham and Frederic--the photographic and theatrical aspects of Crane's prose; his abandonment of narrative conventions in pursuit of a more "authentic" reality. Mariani, for example, reads Red Badge as a novel of spectacular descriptions--vivid scenes which would satisfy the embryonic consumer society of the 1890 s' $^{\prime}$ desire for thrilling spectacle (Mariani, 4). For Amy Kaplan, realism is a "representation of reality struggling against other forms of representation" (Kaplan, 1986, 13). This definition restores to realism its "dynamic literary qualities" by integrating it with the social context out of which it developed: Red Badge struggles with other representations of late 19th century reality--popular war novels, chivalric romances, jingoistic journalism. Thus although much of the early critical scrutiny of Red Badge boiled down to biographical speculation and nationalistic cheerleading, we can be grateful to those few reviewers who realized Red Badge was doing important cultural work. Their analyses suggest some of the reasons why Red Badge became the standard against which all of Crane's subsequent work was measured. 


\section{CONCLUSION}

Early reviews of Red Badge raised three issues that will remain of central interest to the remainder of this project. First, there is Crane's concern with authenticity. Written in a post-photographic age, Red Badge discards contemporaneous conventions of battlefield prose for a discontinuous succession of "flashing images" that yield "photographic revelations." Crane limits the novel's point of view and fragments its narrative in order to focus the impact of each of his "battle pictures" and make us see the truth of his descriptions. Second, although much of General McClurg's commentary about Red Badge's lack of patriotism, for example, is overheated and irrelevant, he was not entirely wrong to suggest that Crane's novel raised potentially disquieting questions about the state of turn-of-the-century American society. The next two sections of this project confront some of those questions. And finally, while Crane's early critics did not realize that Red Badge is set at the Civil War battle of Chancellorsville, subsequent scholarly inquiry has revealed this to be the case. The next section of this project, "The Battle: Chancellorsville," suggests that Crane drew on literary and pictorial sources in order to establish the factual framework of Chancellorsville as the setting for Red Badge. 


\section{The Battle: Chancellorsville}

\section{INTRODUCTION}

In Stephen Crane's short story, "The Veteran," published a year after The Red Badge of Courage, an elderly Henry Fleming reminisces about his first experiences in battle: "That was at Chancellorsville," he remembers. The veteran Henry's recollection of his reasons for flight match those of his younger namesake in Red Badge, and he recalls with sorrow the death of Jim Conklin, the "tall soldier." "The Veteran," then, explicitly identifies the battle in Red Badge as Chancellorsville (May 1-3, 1863), one of the bloodiest struggles of the Civil War. If such fictional correspondence seems slight evidence for the claim that Red Badge is set at Chancellorsville, then we can turn to Crane's earliest biographer, Thomas Beer, who reveals that in preparation for the writing of Red Badge, Crane consulted Battles and Leaders of the Civil War (1884), a collection of memoirs by Union and Confederate officers (Beer, 97-98). Though devoid of emotion, these authoritative accounts are full of all the strategical and topographical information Crane needed to employ Chancellorsville as the setting for his novel. The paragraphs below argue that Crane used the literary and pictorial inspirations of Battles and Leaders to provide a specific factual framework for Henry's experiences in Red Badge. Thematically, Crane utilized the battle of Chancellorsville in order to mount a critique of the fin de siecle American situation: the beleaguered position of the individual in a mass society, the harmful illusions of popular notions of heroism, and the abandonment, in materialistic gestures of denial, of the program of Reconstruction begun in the Civil War. 
Crane's interest in Chancellorsville may very well have begun at home in Port Jervis, New York. Many of the men in the 124th New York, which saw action at Chancellorsville, were from Port Jervis. No doubt Crane heard plenty of war stories as he grew up. Crane's brother, Edmund, was "an expert in the strategy of Gettysburg and Chancellorsville," and Crane no doubt consulted him during a summer of work on Red Badge (Mitchell, 16). Of equal importance to Crane's vision of war are the many illustrations in Battles and Leaders which provided him with subjects for description: the huts at the Falmouth winter camp; pontoon bridges across the Rappahannock; the Chancellor House in the center of the battlefield; and the rout of the Eleventh Corps. Although the novel itself makes no specific mention of the name of the battle which provides the setting for Henry Fleming's initiation into war, a consideration of available evidence leaves very little doubt that Red Baidge takes place at Chancellorsville.

\section{GEOGRAPHY AND CHRONOLOGY}

There are only three geographical locations explicitly mentioned in Red Badge: Washington, Richmond, and the Rappahannock River. Chancellorsville, the first major engagement of 1863, was fought in Northern Virginia near the Rappahannock during the heavy rains of early spring. Chronological analysis confirms this date and location: the novel cannot be set in 1861, as the Civil War began in April of that year and the Northern army would not have spent the winter in camp; the early eastern battles of General George McClellan's Peninsular Campaign of 1862 were fought far away from the 
Rappahannock; though the Battle of the Wilderness was fought in 1864 near that river, it did not, unlike Chancellorsville, end in a Union defeat; and by the time the spring rains of 1865 had passed, Lee had surrendered to Grant at Appomattox. The only possible year that Red Badge can logically be set in is 1863; Chancellorsville was fought in May of that year. That the events in Red Badge happen before Gettysburg is made clear by the loud soldier's comment that thus far in the war the South had licked the North at "about every clip" (Crane, 129). No Union soldier would have made such a statement after Gettysburg.

Red Badge begins with the Union Army encamped north of the Rappahannock river. To the south can be seen the "red eyelike gleam" of Confederate campfires. The army has been in camp for some time, as the soldiers have built semi-permanent structures in which to live: soon after the "youthful private," Henry Fleming, is introduced he retreats into a structure of "log walls" with a "folded tent" for a roof and a fireplace with a clay chimney (Crane, 116-17). Henry wonders if the army will ever see action. After its glorious reception in Washington, Henry's regiment has settled down to "months of monotonous life" in what seems an "eternal camp" and done little but "sit still and try to keep warm." With the arrival of warmer weather, the soldiers are "drilled and drilled and reviewed, and drilled and drilled and reviewed" (Crane, 120). Crane's description of the situation of the Union army in Red Badge is drawn directly from that of the actual Army of the Potomac in April, 1863. The army's members had had time to build temporary cabins, having spent much of the winter encamped at Falmouth, Virginia, on the north bank of the Rappahannock River opposite the Confederate army (Hungerford, 522). With the arrival of new commanding general Joseph Hooker, the 
Union troops were subjected to hours of drill and review. Like many of these troops, Henry and his regiment have never seen battle before.

The "tall soldier," Jim Conklin, breaks up the monotony of long months in camp with the news that "We're goin' $t$ ' move $t$ ' morrah--sure....We' re goin' way up the river, cut across, an' come around in behint em" (Crane, 115). When other soldiers question the veracity of his account, Jim continues: "Didn't the cavalry all start this morning?....They say there ain't hardly any cavalry left in camp. They're going to Richmond, or șome place, while we fight all the Johnnies. It's some dodge like that" (Crane, 122-23). Although the next morning comes and the army does not move, Jim's prediction is eventually borne out. When eleven thousand Union cavalrymen left the Falmouth camp on April 13th for a raid on the Confederate rail lines near Richmond, no doubt many soldiers jumped to the same conclusion (Hungerford, 523). But the Army of the Potomac did not in fact leave camp until two weeks after the departure of the cavalry. In Red Badge, there is a similar delay: Henry muses "for days" about whether or not he will run from a battle. And late in the book, Jim's prediction about Union strategy is confirmed in another soldier's exclamation: "Didn't I tell yeh we'd come aroun' in behint em? Didn't I tell yeh so?" (Crane, 230).

\section{LEAVING CAMP}

When Henry's regiment, the 304th New York, finally leaves camp, they march west and express "commiseration for that part of the army which had been left upon the 
river bank" (127). Campfires are lit that night; the next night the regiment crosses the river on two pontoon bridges and camps again (Crane, 131). These troop movements mirror the march of the Second Corps of Hooker's army: while some of its divisions stayed behind to conduct a holding action against General Robert E. Lee, much of the Second Corps left Falmouth on April 28 and crossed the Rappahannock on two pontoon bridges the evening of April 30.

\section{FIGHT AND FLIGHT}

On May 1, 1863, General Robert E. Lee defied military convention by dividing his already numerically inferior army and sending half of his troops to intercept Hooker's flanking army. Two days after the river crossing, a date that corresponds to May 2, 1863, the first real day of fighting at Chancellorsville, Henry's regiment sees its first action. The regiment is moved three times before lunch, eventually coming back, in the afternoon, to the same territory that they had covered that morning. After the brigade in front of them is routed and flees, Henry's regiment is called to the front and initially resists the charging enemy. But when the Confederates attack again, Henry bolts. These movements roughly, but not directly, parallel those of many regiments at Chancellorsville--many regiments of the Second Corps did first encounter the enemy in mid-afternoon (Hungerford, 524). And Henry's 304th, like many regiments of the actual Second Corps, is in the middle of the Union lines--the "cheery" soldier who later sheperds Henry back to his regiment says: "Th' 304th N'York?...they're way over there in 
the center."

The path of Henry's retreat from the battle is untraceable, but topographical evidence supports the hypothesis that Henry's flight took him west from the Union center toward the Eleventh Corps on the Union right. Henry crosses several streams and goes through cleared fields and dense woods; at one point he finds himself "almost into a swamp" where he has to "walk upon bog tufts, and watch his feet to keep from the oily water" (Crane, 155). Such terrain stood between the center and the Eleventh Corps' position. The scene of Jim's death, which occurs during Henry's flight from the front, is appropriate to the battle of Chancellorsville, as well. The roads leading back to the Rappahannock River were full of Union wounded during the afternoon of the first day's fighting. Many men died while they walked, as ambulances were not able to cope with the numbers of casualties.

\section{JACKSON'S ROUT OF THE XI CORPS}

Perhaps the most well-known event at Chancellorsville is Confederate General Thomas Johnathan "Stonewall" Jackson's rout of the Union Eleventh Corps. This action is renowned because it most likely won the battle for Lee but also cost Jackson his life. After a daring flanking march late in the day on May 2, Jackson's troops attacked the Eleventh Corps, located on the extreme right of the Union line. Unprepared, the Corps' soldiers panicked and fled, leaving the unprotected rear of the entire army open to a Confederate assault. But Jackson's men were confined to the road in the thickly wooded 
area, and a brave charge by the Eighth Pennsylvania cavalry--the only cavalry charge at Chancellorsville--was able to hold off the Confederates' advance long enough for Union artillery to be brought up and employed (Hungerford, 526). The sun set before Jackson could renew his potentially catastrophic rear assault on the Union forces. That evening, returning from reconnoitering enemy territory, Jackson and two of his aides were shot by nervous Confederate pickets. Jackson's left arm was amputated and he later died. It is during Crane's fictional account of Jackson's routing of the Eleventh Corps that Henry receives his "red badge of courage."

\section{THE "RED BADGE"}

Near the end of the day of Henry's flight--"landmarks had vanished into the gathered gloom"--he encounters a mass of men running from the front: "They sometimes gabbled insanely. One huge man was asking of the sky, Say, where de plank road? Where de plank road?"' (Crane, 175). Many of the Eleventh Corps' soldiers were German, and popular stereotypes held that all Germans were large, burly men; to Henry's untrained ear rapidly-spoken German might sound like "gabbling" (Hungerford, 527). When Henry stops to question one of the fleeing soldiers, the harried man hits him in the head with the butt of his rifle. Dazed and bleeding, Henry hears the "grumble of jolted cannon" being drawn to the front: "Into the unspeakable jumble in the roadway rode a squadron of cavalry....There was a mighty altercation" (Crane, 176). Crane describes the arrival of the aforementioned Eighth Pennsylvania Cavalry, the brave detachment that thwarted 
Jackson's advance and prevented the rout of the Eleventh Corps from becoming a complete disaster. The factual framework of Chancellorsville is utilized to place Henry in the middle of that battle's most important single action. The fact that Henry receives his wound from a soldier on his own side emphasizes the fratricidal aspect of the conflict and also the Union army's disarray and vulnerability. At this point in the battle, the fate of the entire Eleventh Corps, and with it that of the Union, hung in the balance.

\section{HENRY'S RETURN}

Under cover of darkness, the cheery soldier returns Henry to his regiment, where his wound is bandaged by the now softspoken loud soldier. During the next day of fighting, the men of the 304th New York are sent out "to relieve a command that had lain long in some damp trenches" (Crane, 192). Earlier in the novel Crane describes the construction of such trenches: "[The men] used stones, sticks, earth, and anything they though might turn a bullet." Some of the new men wish to stand erect and fight like duelists, but they quickly take a lesson from the veterans, who are "digging at the ground like terriers" (Crane, 136). The regiment is withdrawn briefly before being ordered on a dangerous last-ditch charge to preserve the integrity of the Union lines. On May 3, as Jackson's men fought to rejoin the main body of Lee's army, Gen. Hooker had ordered a Union retreat, but then sent the 124th New York regiment--a group comprised of men from Port Jervis, Crane's hometown--on a charge against the enemy (Hungerford, 528). The location of this episode--about a quarter-mile south of Fairview--is rendered with 
almost photographic accuracy; Crane describes a "slope on the left" of Henry from which a row of guns fired at the Confederates. In the rear of the cannons "stood a house, calm and white, amid bursting shells . A congregation of horses, tied to a railing, were tugging frenziedly at their bridles. Men were running hither and thither" (Crane, 219-20). Crane depicts the Chancellor House, which served as headquarters for Hooker and the other Union generals--their horses and orderlies were no doubt attempting to run for cover.

\section{ADVANCE AND RETREAT}

The final charge of Henry's regiment has possible parallels to a charge made by several regiments of the Second Corps later in the morning on May 3. The charge was an effort to give the bulk of the army time to withdraw the cannons from the hilltop and begin the general retreat. Crane describes the conditions of the retreat: "It rained. The procession of weary soldiers became a bedraggled train, despondent and muttering, marching with churning effort in a trough of liquid brown mud under a low, wretched sky" (Crane, 231). The beginning of this retreat from battle marks the end of Red Badge, but for the Union Army at Chancellorsville the rains continued, preventing for two days attempts to cross the Rappahannock. The Union had reached its lowest point, in war and in spirit, a point which should be kept in mind when considering Crane's portrait of Henry at the conclusion of the novel. The concluding paragraphs of Red Badge might be said to accurately describe the physical and spiritual "state of the Union" after Chancellorsville. 


\section{CONCLUSION}

The question remains: why did Crane avoid specifically naming Chancellorsville in Red Badge? The easiest answer is that none of the characters in the novel--certainly not lowly privates like Henry Fleming--would have known that the battle they were fighting in was to be called Chancellorsville. Civil War reports and memoirs reveal that the men fighting the war very seldom knew where they were, as they often fought on unfamiliar territory and had infrequent communication with field commanders. (As in Red Badge, the regiments often knew only rumors.) Another reason for the battle's anonymity is that Crane was not interested in providing a panoramic, "band-box" view of war (as in Tolstoy and Zola) or a highly detailed, abstract accounting after the fashion of the generals who contributed to Battles and Leaders of the Civil War. The decision to avoid naming the battle was at least partly a technical one: doing so might have loosened Crane's authorial control, as the word "Chancellorsville" might conjure up memories and reactions unrelated to the experience of reading Red Badge. It is important for the reader to know that Henry fights at Chancellorsville but it is not realistic that Henry himself should realize this.

Crane's power as a writer is evident in his skillful employment of the facts of Chancellorsville for his own fictional purposes, and there are of course some very important thematic reasons for Crane's use of this particular battle. Chancellorsville was the first battle of 1863 , as well as the first combat experience for many of the green Union recruits. Henry and his regiment are similarly untried, and much of the novel's drama 
comes from their speculation and introspection about how they will hold up under fire. Heroic Confederate actions at Chancellorsville went only to prolong a losing cause. The Northern generals proved (again) that it was possible to considerably outnumber one's enemy and still lose the battle. Crane uses this pyrrhic bloodbath to argue for the replacement of the "martial ideal" of individual heroism in favor of a more communitarian code--one which would give place to the forgotten Negro teamster who interests the soldiers briefly at the outset of the novel but "sits mournfully down" after their interest shifts to feats of battle. Crane's indictment of an America which has reneged on Reconstruction is subtle but unmistakable. For when Chancellorsville was over, twenty-seven thousand men were dead but both sides were more or less where they were when it began (Mitchell, 17). Red Badge conveys a similarly pyrrhic sense of victory: the Union forces retreat from the field in a downpour, crossing the river to end up where they had begun.

Setting, of course, does not a novel make--the significance of Crane's style remains to be discussed. Though he wrote Red Badge with a definite battle in mind, Crane kept the proper names of places and people almost completely out of his narrative in order to focus unrelentingly on an unseasoned private's emotional responses to the dreadful corpse-producing machine of war--images matter in Red Badge, not names. Recall what Harold Frederic located as a defining quality of Crane's prose: its ability to yield a "photographic revelation;" remember, too, that George Wyndham suggested that Crane's depiction of war admits the reader "as to a theatre." Building on the above assertion that Crane utilized illustrations from Battles and Leaders of the Civil War in his 
effort to "image" the war, the concluding section of this project, "Imaging the Civil War: Authenticity in Painting, Photography and The Red Badge of Courage," speculates about the influence on the novel of several other popular visual representations of the Civil War, images which persisted in the public imagination. 


\section{Imaging the Civil War: Authenticity in Painting, Photography, and The Red Badge of Courage}

"[Henry's] mind took a mechanical but firm impression, so that afterward everything was pictured and explained to him, save why he himself was there."

--The Red Badge of Courage, 206.

\section{INTRODUCTION}

Early reviewers speculating about possible influences on The Red Badge of Courage usually mentioned European realist novelists like Tolstoi, Zola, and Kipling. Subsequent analyses, including the previous section of this project, have suggested that Crane drew on both literary and pictorial sources in the writing of Red Badge: he consulted Battles and Leaders of the Civil War (1884), a collection of Union and Confederate officers' memoirs which included many illustrations based on wartime sketches and photographs. But Crane's debt to the style and subject matter of visual representations of the Civil War by American artists--photographs by Mathew Brady, Alexander Gardner, and Timothy H. O' Sullivan; paintings by Winslow Homer and others--has gone largely unremarked. Many scenes in Red Badge reinforce and/or re-interpret the persistence and place of these representations in the popular imagination about the war. Crane's "battle pictures" of the Civil War debunk the narrative strategies of popular fiction of his day--chivalric historical romances, popular war novels with domestic subplots, veterans' martial memoirs. With a minimum of a linking narrative, 
Crane's vivid images of Henry's initiation into war question assumptions about the War's significance which prevailed in the Gilded Age.

Red Badge is only one instance of the rhetoric of the decade which recalled Americans to the "heroism of the civil War generation" (Lears, 113). Red Badge appeared in a time when fraternal meetings between Blue and Gray veterans celebrated each others' heroics and reinterpreted Civil War battles as a way to transcend conflict rather than discuss politics. Postreconstruction period military histories and domestic fiction "excised political conflict from the collective memory of the war" (Kaplan, 1986, 80). Social conflict--urban unrest, labor strikes--could be temporarily submerged in the veterans' rhetoric of national unity. Internal conflicts were rewritten as a celebration of mutual American manhood and then refocused on imperialistic external conflict--the Philippines, the Spanish-American War, etc. Contemporaneous with these trends was a resurgence in the popularity of Scott-style historical romances and war novels. Red Badge reveals the ways in which these recontextualizations of the Civil War are unsatisfactory.

\section{CRANE AGAINST CONVENTIONS}

\section{Martial Ideal}

Crane parodies the popular chivalric romances of his day in his early portrait of Jim Conklin. The tall soldier "develops virtues" and goes to "wash a shirt," waving it as if he were "a herald in red and gold" (Crane, 113). This description makes fun of the "martial spirit" so popular in the rhetoric of the jingoists and in Teddy Roosevelt's notion 
of the "strenuous life." According to T. J. Jackson Lears, the "martial ideal" emerged in 1890s America as a popular antidote to enervated refinement, a premodern alternative to lackluster industrial man: "In the excitement of postwar economic expansion, it seemed to many that commercial necessity had rendered the martial virtues obsolete...nearly all agreed that modern civilized man was rational, self-controlled, and anxious to avoid violence" (Lears, 100). This amounts to a paraphrase of Henry Fleming's early musings about battle: "Greeklike struggles would be no more. Men were better, or more timid. Secular and religious education had effaced the throat-grappling instinct, or else firm finance held in check the passions" (Crane, 120). Henry, like so many men in the 1890s, wondered about the passing of opportunities for masculine assertions and worried that the days of martial glory were over.

The Southern cultivation of the "Lost Cause" fed into the chivalric notions of what Lears calls the "martial ideal." "The Last Meeting between Lee and Jackson," one of the central icons of the Lost Cause, displays the two demigods of the Confederate army in conference--at Chancellorsville, the evening before Jackson was fatally wounded--about how best to wrest glory from the battlefield. The descriptions of generals in Red Badge emphasize their quasi-divine status. They are far removed from the fray; they hold conferences in which they denounce the common troops; Henry passionately resents them and thinks them unable to understand him. Nonetheless, he aspires to martial greatness. After his initial secession from the regiment and withdrawal into self-analysis, Henry rejoins and fights like a "war devil." Throwing himself into the regiment's struggle against the enemy, he feels a "sublime moment of selflessness" but is unable to rid 
himself of the memory of his earlier desertions (of the regiment and the tattered soldier). Lears: "Reacting against therapeutic self-absorption, the cult of martial experience proved unable to transcend it" (Lears, 138). This seems to be Henry's experience, as well. Red Badge may celebrate combat to a point, but it does not uncritically participate in the militaristic national cheerleading that was commonplace in the late $1890 \mathrm{~s}$.

\section{Domestic Subplots}

Many of the Civil War novels of the 1880s and 1890s included domestic subplots in which sectional differences were reconciled through marriage between houses (the Union officer marries the Southern belle). Popular paintings like "The Consecration" depicted the soldier and his faithful lover: they say goodbye as he leaves for war, kissing symbols of one another's sex. The painting evokes past epochs in which knights fought for the affections of a lady; it suggests impending domestic harmony. Crane appears interested in this idea when he introduces the dark-haired maiden who looks longingly after Henry as he leaves for war (Crane, 120). But she is abruptly dropped; this is the last readers see of her. Crane abandons the domestic subplot to emphasize that there is to be no joining of the houses in Red Badge, no easy reconciliation.

\section{Veterans' Tales}

Crane's revolt against the domestic realism of his precursors--the aristocratic 
refinement of James and Howells--and the easy answers of popular fiction is rooted in his own apprehension about the crisis of cultural authority. Early on, Henry Fleming expresses doubts about the veracity of veterans' accounts of the enemy: "[H]e could not put a whole faith in veterans' tales, for recruits were their prey. They talked much of smoke, fire, and blood, but he could not tell how much might be lies. They persistently yelled, 'Fresh fish!" at him, and were in no wise to be trusted" (Crane, 121). Henry questions the power of historical authority--the words of the veterans--to assure continuity into the present. War stories often obscure as much as they reveal, Crane suggests, in what must be seen as a commentary on the contemporary phenomenon of Confederate and Union veterans getting together to re-interpret the war as glorious testimony to their mutual manhood.

Fraught with the opposed tensions of economic incorporation and increasing social diversity, art in the antebellum age often revealed the ways in which personal identity and political unity were at cross purposes. The Civil War radicalized such concerns and caused individual Americans to wonder what, if anything, could be said to continue to attach to the term 'American character' or even 'American nation.' With traditional religion weakened and antebellum notions of superintending Providence discredited, what remained to organize and give meaning to individual and national actions? Such questions were exacerbated by the change from entrepreneurial to corporate capitalism in late-19th century America. For Crane, at least, the Civil War became a metaphor for the individual's experience in the age of incorporation and mass society. Jackson Lears suggests that these years saw "a shift from a Protestant to a 
therapeutic orientation within the dominant culture" (Lears, xiv). This "therapeutic orientation" included the fin de siecle yearning for authentic individual experience--physical, emotional, or spiritual. Red Badge is about Henry's search for such experience, for "the real thing."

\section{"HOW DO WE LEARN TO SEE?"}

Commenting on Red Badge's reliance on previous visual representations of reality, Miles Orvell suggests that Crane's work often raises the question: "How do we learn to see?" (Orvell, 127). For Henry James and W. D. Howells, the artist's studio and the editor's desk were the class-bound shops in which the realist's artful illusions were fabricated. Crane's journalistic approach took him out of the studio and into the streets in an effort to comprehend the relation between diverse sections of an increasingly heterogeneous American society--witness the slum life of Maggie and "An Experiment in Misery," the beleaguered individuality of Red Badge's provincial private. Crane's fiction concerns itself with the "democratization of literary representation" and the "struggle to forge bonds between members of antagonistic social classes" (Kaplan, 1988, 22). Crane put the project succinctly: "Culture, in its true sense, I take it," he wrote in an 1895 letter to a friend, "is a comprehension of the man at one's shoulder" (Delbanco, 49). The pursuit of such inter-class comprehension separates Crane's fiction from that of James and Howells and informs his attempt to find an authentic alternative to the dangerous self-deception and facile transcendence of the popular fictions of his day. 


\section{A NEW EYE}

The advent of the daguerreotype in 1839 and its subsequent popularity in the United States radically modified the notion of "the real" in representation, and irrevocably changed ideas about what constituted "history" and "literature." Pictures were thought to be truthful to reality in a way that language could never be. The camera's truth-telling capacities were celebrated as a significant step toward the apprehension of things as they really existed. Photographs offered individual vividness as a substitute for a clear, shared understanding of some "larger" reality. As implied in Harold Frederic's review, Red Badge is a series of 'imaged' moments tenuously linked by narrative, a presentation of 'history' in the manner of Eadward Muybridge's photographic exhibit. In battle, Henry's mind takes a "mechanical but firm impression" so that afterward everything is "pictured and explained to him, save why he himself was there" (Crane, 206). The "battle pictures" are vivid, but discontinuous, leaving Henry--and the reader--uncertain about how (and if) the succession of impressions relate to one another. This has been a problem for readers of Red Badge from its appearance; General McClurg groused that the novel lacked both plot and character development (Crane had "absolutely no story," he concluded).Crane's battlefield prose frustrated (and exhilarated) readers because of its refusal to conform to generic expectations. One of the reasons for this is Crane's debt to visual artists rather than literary precursors.

\section{BATTLE PICTURES}


Many similarities unite Crane's novel with visual representations of the Civil War by American artists. Subjects in the work of Crane, Brady, and Homer often appear unadorned, unexceptional, anonymous--Henry Fleming, who thinks himself only part of a "vast blue demonstration;" Brady's unidentified Union and Confederate dead; Homer's isolated sharpshooter and his solitary, anonymous "veteran in a new field." The selection of the Civil War as subject for their work ties Brady, Crane, and Homer together in other important ways: as chroniclers of fratricidal strife and social unrest; as critics of an increasingly impersonal mass society; and as explorers who attempt to portray an authentic, shared "reality." Crane's language in Red Badge looks for an originary force behind the war, behind the actions of individuals, behind life and death. It describes the world in various ways but never claims to correspond to 'reality': illusions are created and destroyed and reborn; colors, surfaces, and vivid impressions all stand in for self-knowledge (and, perhaps more significantly, knowledge of what is shared with others). Henry Fleming's moral predicament is that he needs to connect his body's battle experience with the heroic ethos he has absorbed from storybooks and pictures.

Early photographic exhibits recognized the problems of trying to tell a story with images. Alexander Gardner's Photographic Sketchbook of the Civil War (1866) was accompanied by an organizing narrative which aimed to ensure that the images, so powerful in and of themselves, would be interpreted by viewers in the right way. Individual images could be isolated, discontinuous and misleading; they needed an encompassing structure--the program's text--to give them status as segments in an unfolding epic event. Orvell points out that Gardner "played on his audience's belief in 
the veracity of the medium while taking for himself a much more flexible view of photographic practice," one in which "the manipulations of the photographer were permissible in the interest of achieving a rhetorically convincing effect" (Orvell, 96). As Trachtenberg sees it, the central motive of Gardner's Sketch Book is the transformation of scenes of war into sacred memories, into monuments. Red Badge, by contrast, does not aim to transform scenes of war into sacred memories; it uses them to invoke past traumas which have been submerged in the national consciousness, to remind readers of personal and social responsibilities left unfulfilled.

\section{THE WAR'S "DUAL REPRESSIONS": RACE AND DEATH}

\section{Race}

At the beginning of the novel, Crane dramatizes the abandonment of the issue of emancipation as a central concern of the war: "A negro teamster who had been dancing upon a cracker box with the hilarious encouragement of two-score soldiers was deserted. He sat mournfully down" (Crane, 115). Although Crane explores the complex symbolic qualities of blackness throughout the rest of the novel, he never again mentions the issue of slavery or speaks of the Civil War as a struggle for emancipation of the slaves. Except for a minority of abolitionists, Northern leaders deferred as long as possible facing or even naming slavery as a factor in the Civil War, let alone race hatred and doctrines of inferiority. The paucity of blacks in the photographic record of the war, their appearance 
on the margin of scenes, "parallels their status within the mental pictures that screened the mind from the full social and political facts of the war" (Trachtenberg, 80). The photograph "Burial Party, Cold Harbor, Va." exemplifies what Trachtenberg terms the "dual repressions" of the war: the issues of race and violent, undignified death. It is to Crane's moral credit that he spares neither of these subjects in Red Badge, that he chooses instead to interrupt the materialistic gestures of denial of his Gilded Age readers with a reminder that the Civil War was fought for emancipation. As Ralph Ellison has written, the nation's reneging on Reconstruction might be thought of as the "continuation of the Civil War by means other than arms" (Ellison, 67). Crane reminds his readers that America has turned away from those it promised to help.

\section{Death}

Civil War photographs challenged popular cultural conceptions long in place: they portrayed not heroic action in a grand style but instead a collection of dirty, disheveled soldiers and rotting corpses--boredom and death rather than chivalric grandeur and heroic invincibility. The depiction of the casualties of war in Red Badge owe obvious debts to popular photographs of the Civil War by Brady, Gardner, Alexander Russell, and Timothy H. O' Sullivan. The description of the aftermath of the Union Eleventh Corps' retreat calls to mind an Alexander Russell photograph of the carnage at Marye's Heights, Chancellorsville: "The little narrow roadway now lay lifeless. There were over-turned wagons like sun-dried boulders. The bed of the former torrent was choked with the bodies 
of horses and splintered parts of war machines" (Crane, 177). "The Dead at Antietam"

and "Harvest of Death" are perhaps the two most famous visual representations of

casualties from the fighting. Here is Henry's first encounter with a dead soldier:

He lay upon his back staring at the sky. He was dressed in an awkward suit of yellowish brown. The youth could see that the soles of his shoes had been worn to the thinness of writing paper, and from a great rent in one the dead foot projected piteously. And it was as if fate had betrayed the soldier. In death it exposed to his enemies that poverty which in life he had perhaps concealed from his friends.

The ranks opened covertly to avoid the corpse. The invulnerable dead man forced a way for himself. The youth looked keenly at the ashen face. The wind raised the tawny beard. It moved as if a hand were stroking it. He vaguely desired to walk around and around the body and stare; the impulse of the living to try to read in dead eyes the answer to the Question. (Crane, 134).

Henry wants answers, as did Crane and his readers. The Civil War was an event of considerable magnitude and purpose, a subject of incredible depth for artists, one which needed desperately to be explained, if not actually justified. After all, no one could even agree on the causes of the war, on its meaning as a political and moral event: four years of brutal fighting, half a million casualties, devastation of land and cities: was it fratricidal conflict,' rebellion spawned in conspiracy, holy crusade, struggle between two nations?

The following passage calls to mind Mathew Brady's photo of the dead of Antietam:

Under foot there were a few ghastly forms motionless. They lay twisted in fantastic contortions. Arms were bent and heads were turned in incredible ways. It seemed that the dead men must have fallen from some great height to get into such positions. They looked to be dumped out upon the ground from the sky. (Crane, 146). 
In his flight from the fighting, Henry enters a clearing, a cathedral-esque place filled with a "religious half light." Here he discovers the decaying corpse of a Union soldier.

He was being looked at by a dead man who was seated with his back against a column-like tree. The corpse was dressed in a uniform that once had been blue, but was now faded to a melancholy shade of green. The eyes, staring at the youth, had changed to the dull hue to be seen on the side of a dead fish. The mouth was open.

Its red had changed to an appalling yellow. Over the gray skin of the face ran little ants. One was trundling some sort of a bundle along the upper lip.

The youth gave a shriek as he confronted the thing. He was for moment turned to stone before it. He remained staring into the liquid-looking eyes. The dead man and the living man exchanged a long look. (Crane, 156)

This "look" might be analogous to Crane's own initial exposure to the Civil War dead in photographs like those of Brady and $O^{\prime}$ Sullivan. When Henry finally breaks the hold of the dead man's gaze, he runs away, "pursued by a sight of the black ants swarming greedily upon the gray face and venturing horribly near to the eyes." This sight horrifies Henry because it threatens his ability to observe the war. His spectatorship depends on his vision; after deserting his regimental responsibilities, it is Henry's only remaining aid in making sense of the scenes around him.

\section{WOUNDS OF WAR}

It should be clear by now that the depictions of the dead in Red Badge owe much 
to Civil War photographs. Ultimately, however, Crane is more interested in the significance of the wounded. The bleeding, addled aspect of the "tattered soldier," the grimly realistic rendering of Jim Conklin's death, and of course Henry's own "red badge"--these are the physical evidence of the war's spiritual and ideological struggles. Writing about the medical photograph albums of wounded soldiers, Trachtenberg suggests that: "[T]he living wounded body is the final untellable legend" (Trachtenberg, 116). Red Badge concludes with a similar sense of the inscrutability of wounds: Henry Fleming's red badge masks the secret with which he must live at the conclusion of the war, a reminder of his desertion of the tattered soldier and the death of Jim Conklin. In a later work, "The Monster," Crane relates the story of Henry Johnson (it is interesting that this character shares Fleming's name), a horribly disfigured ex-slave who suffers prejudice in a post-bellum Northern town. Henry's wound and his outcast status invoke the horror of racial violence and the abandonment of emancipation efforts in the United States. Henry Fleming's red badge of courage is a symbol of the knowledge which keeps him distant from his fellow soldiers. Despite his re-integration into the regiment in the fighting which concludes the novel, Henry remains isolated, an individual in precarious, antagonistic relation to those around him.

\section{A PRIVATE WAR}

Henry Fleming has precursors in the Union soldiers that are the subjects of Winslow Homer's Civil War paintings. Three decades before Crane came to international 
recognition for Red Badge, Homer had established himself on the art scene with his revolutionary representations--illustrations for Harper's Weekly--of the Civil War. "The Sharpshooter," one of his first paintings of the war, portrays a solitary soldier seated in the crook of a tree branch, sighting a target out of the view of the observer. Isolated, the shooter appears vulnerable, open to a shot from an enemy sniper. Homer's painting is testimony to his apprehension of the modernity of the war: the lone sharpshooter, armed with his extremely accurate modern rifle, replaces the vast Napoleonic cavalry charges of previous battlefield paintings. Homer himself found that, measuring by traditional standards of gallantry, the sharpshooter's impersonal death-dealing was "butchery" (Cikovsky, 16). Crane focuses in a similar fashion on Henry Fleming, at once reducing the scale of the war and intensifying its effect. Henry, who thinks himself alone among his peers, is eternally vigilant for enemies--within and without.

"Home Sweet Home," the second of Homer's paintings to garner attention, was painted while observing the Army of the Potomac during the Peninsular Campaign in 1862--the following spring this army fought at Chancellorsville. A pair of Union soldiers (infantrymen, like Henry Fleming) in camp listen to the regimental band play nostalgic songs. The feeling of the painting is recreated in Henry Fleming's evening reminiscences after a day of marching and fretting about his fitness for war: "He wished, without reserve, that he was at home again making the endless rounds from the house to the bar, from the barn to the fields, from the fields to the barn, from the barn to the house...he would have sacrificed all the brass buttons on the continent to have been enabled to return" (Crane, 129). Crane's description of Henry's restless melancholy in the "eternal 
camp" at Falmouth has a precursor in Homer's camp-bound soldiers. They all brood in their new "home," the theatre of war.

\section{"THE RIGHT TO ANTAGONIZE"}

Late in Red Badge Henry's regiment makes a successful charge and manages to capture a Confederate flag and take four prisoners. Crane's account of these prisoners might be drawn from two separate sources: a photograph of some Confederate troops captured at Gettysburg and Homer's painting, "Prisoner's From the Front." The Gettysburg prisoners pose proudly for the camera: one man splays his hands out across his lapels like a dandy; another leans on one bent leg against a pile of rails (Crane's prisoners are taken near a rail fence, as well); the third gazes stoically into the distance. In Homer's painting, perhaps the most celebrated of his Civil War canvases, a Union officer appraises three Confederate prisoners escorted from the front. To the far left, a stolid-faced, poor-white yokel slumps before the general's authority. On the right, the brash, impudent, courtly Virginian refuses to give any deference to the shorter Union commander. In the middle of these two stands an old man, clearly uncertain about what his situation and holds for him. The mix of insolence and resignation that appears in the Gettysburg photograph and in Homer's three prisoners resonates in Crane's depiction of the Confederates captured by Henry's regiment:

The third captive sat with a morose countenance. He preserved a stoical and cold attitude. To all advances he made one reply 
without variation, Ah, go $t^{\prime}$ hell!'....The last of the four was always silent and, for the most part, kept his face turned in unmolested directions.... The youth could detect no expression that would allow him to believe that the other was giving a thought to his narrowed future, the pictured dungeons, perhaps, and starvations and brutalities, liable to the imagination. All to be seen was shame for captivity and regret for the right to antagonize." (Crane, 226-27)

The lack of North-South reconciliation that critics noted in "Prisoners from the Front" is conveyed with equal emphasis in Crane's portrayal of these captives. The "right to antagonize" drives the war and the men that fight it. Without chances for martial exertion, Crane notes sardonically, these men would feel "doomed to peace and obscurity."

\section{THE VETERAN}

One of the most hotly debated aspects of Red Badge is its conclusion. The extent of Crane's irony is difficult to determine. As the regiment marches in the rain and mud, retreating back across the river to end up exactly where they had started, Henry Fleming smiles.

He had rid himself of the red sickness of battle. The sultry nightmare was in the past. He had been an animal blistered and sweating in the heat and pain of war. He turned now with a lover's thirst to images of tranquil skies, fresh meadows, cool brooks--an existence of soft and eternal peace.

Over the river a golden ray of sun came through the hosts of leaden rain clouds. (Crane, 231)

Winslow Homer's "The Veteran in a New Field" might very well have figured in Crane's concluding imagery. As already noted, Crane's short story "The Veteran," 
published a year after Red Badge, portrays an older Henry Fleming's reminiscences about Chancellorsville and the death of the noble tall soldier. The lone veteran, his uniform shed and lying in a corner of the field, reaps the sheaves of wheat with a scythe. It is easy to imagine this figure as that of Henry Fleming, returned from the war to the farm he had left behind. As he swings the blade, he thinks of his "red badge of courage," of Jim Conklin's death, of the cost and meaning of war. The irony in Homer's painting is as complex and multi-layered as that in Crane's novel. The images convince, but their relation to one another remains unclear; their places in an overarching story remain in doubt.

\section{CONCLUSION}

It has not been the purpose of this project to suggest that Crane crafted Red Badge while seated in front of the paintings and photographs discussed above, that is not likely the case. What is suggested is that the authenticity of Crane's war novel is highly mediated by his reliance on and (re)presentation of popular visual representations of the Civil War. But what does this matter? In Red Badge, "Henry's obsession with seeing suggests that he trades the role of actor for the spectator, to gain both a sense of control and a vicarious thrill from observing the battle at a safe enough distance not to be crushed by it" (Kaplan, 1986, 98). In his later work as a journalist covering foreign conflicts, Crane characterized himself as an observer of spectacle, a "cheap telescope" for the readers back home, away from the action. If the war is a spectacle and Henry a spectator, 
then the process by which Henry sheds the illusions which cloud his observation of the battlefield--the sham visions of chivalric glory, the promise of the intended waiting at home--and becomes capable of registering "mechanical but firm impressions" of the scenes he sees can be thought of as the change from narrator to photographer.

Crane attempts to portray authentic experience through a series of vivid impressions. Fighting in a war without identifiable territorial objectives, Henry senses a loss of individual control and purpose. He acknowledges the irrelevance of rational interpretation and feels acutely the failure of political or religious or philosophical language to make personal catastrophe intelligible. This breakdown of narrative explanation is embodied in Crane's fragmented, discontinuous rendition of Henry's experiences. Red Badge re-presents visual representations of the Civil War in order to critique contemporary attitudes about heroism and nationalism. As such, it is hostile toward the cultural situation of America at the end of the 19th century--the unresolved, unintelligible catastrophe of the Civil War haunted urban unrest, impersonal mass society, political corruption, and social backsliding on efforts toward emancipation. Yet the novel is not strictly an exercise in iconoclasm. The process by which Henry sheds his illusions leads him to assert by novel's conclusion that the antagonistic co-operation necessary to democratic society must be embraced. Such conviction is embodied in the scene in which he struggles with his fellow soldier to uphold the flag on the battlefield. Mingled with the irony of Henry's "education" is a certain wistfulness, however, an .indication that Crane seeks reasons to be pious about America. Red Badge's images of the war urge a regeneration of America's commitment to the rights of each and every one 
of its citizens, a renewal of its democratic energies. Crane asks a recognition from his reader that the virtues Henry achieves only in battle are of utmost importance in everyday life. 


\section{Bibliography}

Angle, Paul. A Pictorial History of the Civil War Years. New York: Doubleday, 1967.

Battles and Leaders of the Civil War (Vol. III). New York: Thomas Yoseloff, 1956.

Bassan, Maurice, ed. Stephen Crane. Englewood Cliffs, N. J.: Prentice-Hall, 1967.

Beer, Thomas. Stephen Crane. Garden City, N. J.: Doubleday, 1923.

Cikovsky, Nicolai. Winslow Homer. Harry N. Abrams Publishers (in association with the National Museum of American Art, Smithsonian Institution), 1990.

The Civil War: A Centennial Exhibition of Eyewitness Drawings. Washington, D. C.: National Gallery of Art (Smithsonian Institution), 1961.

Crane, Stephen. The Red Badge of Courage and other Writings. ed. Richard Chase. Boston: Houghton Mifflin, 1960.

Delbanco, Andrew. "The American Stephen Crane: The Context of The Red Badge of Courage." New Essays on The Red Badge of Courage. New York: Cambridge Univ. Press, 1986.

Ellison, Ralph. "Stephen Crane and the Mainstream of American Fiction." Shadow and Act. New York: Vintage, 1995.

Fox, Richard Wightman and T. J. Jackson Lears, eds., The Culture of Consumption: Critical Essays in American History, 1880-1980. New York: Pantheon Books, 1983.

Giese, Lucretia Hoover. Winslow Homer: Painter of the Civil War. Ph. D. diss., Harvard University, 1985.

Hobart, George. Mathew Brady. London: MacDonald and Co., 1984.

Holzer, Harold and Mark E. Neely, Jr. Mine Eyes have Seen The Glory: The Civil War in Art. New York: Orion Books, 1993.

Hungerford, Harold. R. “That Was at Chancellorsville': The Factual Framework of The Red Badge of Courage." American Literature (34: 4) January, 1963.

James, Henry. The American Scene. New York: Horizon Press, 1967. 
Kaplan, Amy. The Social Construction of American Realism. Chicago: University of Chicago Press, 1988.

Kaplan, Amy. "The Spectacle of War in Crane's Revision of History." New Essays on The Red Badge of Courage. New York: Cambridge Univ. Press, 1986.

Kazin, Alfred. On Native Grounds. New York: Harcourt Brace Jovanovich, 1942.

Lears, T. J. Jackson. No Place of Grace: Anti-Modernism and the Transformation of American Culture, 1880-1920. New York: Pantheon Books, 1981.

Mariani, Giorgio. Spectacular Narratives: Representations of Class and War in Stephen Crane and the American 1890s. New York: Peter Lang, 1992.

McPherson, James M., ed. The Atlas of the Civil War. New York: MacMillan, 1994.

Mitchell, Lee Clark, ed. New Essays on The Red Badge of Courage. New York: Cambridge U P, 1986.

Orvell, Miles. The Real Thing: Imitation and Authenticity in American Culture, 1880-1940. Chapel Hill: University of North Carolina Press, 1990.

Pells, Richard. The Liberal Mind in a Conservative Age: American Intellectuals in the 1940s and 1950s. New York: Harper \& Row, 1985.

Simpson, Marc. Winslow Homer: Paintings of the Civil War. San Francisco (Fine Arts Museums of San Francisco): Bedford Arts, 1988.

Sundquist, Eric J., ed. American Realism: New Essays. Baltimore: The Johns Hopkins $\mathrm{UP}, 1982$.

Sweet, Timothy. Traces of War: Poetry, Photography, and the Crisis of Union. Baltimore: Johns Hopkins U P, 1990.

Trachtenberg, Alan. The Incorporation of America. New York: Hill and Wang, 1982.

Trachtenberg, Alan. Reading American Photographs: Images as History, Mathew Brady to Walker Evans. New York: Hill and Wang, 1989.

Ward, Geoffrey C., Ric Burns and Ken Burns. The Civil War: An Illustrated History. New York: Alfred A. Knopf, 1990. 